\title{
Sources of atmospheric mercury in the tropics: continuous observations at a coastal site in Suriname
}

\author{
D. Müller ${ }^{1}$, D. Wip ${ }^{2}$, T. Warneke ${ }^{1}$, C. D. Holmes ${ }^{3}$, A. Dastoor ${ }^{4}$, and J. Notholt ${ }^{1}$ \\ ${ }^{1}$ Institute of Environmental Physics, University of Bremen, Germany \\ ${ }^{2}$ Anton de Kom Universiteit van Suriname, Paramaribo, Suriname \\ ${ }^{3}$ University of California, Irvine, USA \\ ${ }^{4}$ Air Quality Research Division, Environment Canada, 2121 Trans Canada Highway, Dorval, QC, H9P 1J3, Canada
}

Correspondence to: D. Müller (dmueller@iup.physik.uni-bremen.de)

Received: 17 February 2012 - Published in Atmos. Chem. Phys. Discuss.: 20 April 2012

Revised: 27 July 2012 - Accepted: 10 August 2012 - Published: 16 August 2012

Abstract. Mercury measurements at a coastal site in Nieuw Nickerie $\left(5^{\circ} 56^{\prime} \mathrm{N}, 56^{\circ} 59^{\prime} \mathrm{W}\right)$, Suriname, provide the only continuous records of atmospheric mercury in the tropics. Here we evaluate observations of total gaseous mercury (TGM) during 2007. Nieuw Nickerie typically samples marine air from the Atlantic Ocean, with occasional influence from continental South America. Over the year, average concentrations are $1.40 \mathrm{ng} \mathrm{m}^{-3}$. As the intertropical convergence zone passes over Suriname twice each year, the site samples both northern and southern hemispheric air masses. We use back trajectories to classify each measurement by hemisphere, as well as continental or ocean. For air passing over ocean before sampling, TGM concentrations are $10 \%$ higher in air coming from the Northern Hemisphere $\left(1.45 \mathrm{ng} \mathrm{m}^{-3}\right)$ than from the Southern Hemisphere $\left(1.32 \mathrm{ng} \mathrm{m}^{-3}\right)$. Air from the South American continent also carries higher TGM $\left(1.43 \mathrm{ng} \mathrm{m}^{-3}\right)$ than air from the South Atlantic Ocean, with most of these trajectories occurring in August and September. Biomass burning in Brazil peaks in the same months and likely contributes significantly to elevated concentrations seen in Nickerie. We also compare the observed seasonal cycle to two atmospheric mercury chemistry and transport models (GRAHM and GEOS-Chem). Both models simulate transition between northern and southern hemispheric air, thus capturing the seasonal cycle; however the models overestimate the TGM concentrations during months when Nickerie samples Northern Hemisphere air. It is difficult to determine whether the models' sources or sinks in the Northern Hemisphere tropics are responsible.

\section{Introduction}

Mercury $(\mathrm{Hg})$ is a volatile element that is known to be toxic for humans. Its residence time in the atmosphere can be up to one year (Lindberg et al., 2007), thus it is subject to global transport. The three most important forms of mercury in the atmosphere are gaseous elemental mercury (GEM or $\mathrm{Hg}^{0}$ ), oxidized or reactive gaseous mercury (RGM or $\mathrm{Hg}^{2+}$ ), which is more soluble than the unoxidized species and hence more quickly deposited, and total particulate mercury (TPM), which embraces various mercury species bound to particles (Lindberg et al., 2007). GEM is the most abundant form in the atmosphere, contributing more than $95 \%$ to the total atmospheric mercury (Ebinghaus et al., 1999).

Mercury, in its different forms, enters the atmosphere from a variety of natural and anthropogenic sources (Pirrone et al., 2010). Among the latter, industrial activities, such as energy production by combustion or the chemical industry, constitute a major source of mercury emissions. The majority of industrial activity takes place in the Northern Hemisphere $(\mathrm{NH})$. This is the main reason why the mercury concentrations in the NH are higher than in the Southern Hemisphere (SH). Consequently, one finds a distinctive gradient of mercury concentrations between NH and SH (Sprovieri et al., 2010). Despite a globally observed decrease of the atmospheric mercury burden, the $\mathrm{NH} / \mathrm{SH}$ concentration ratio of 1.48 has remained nearly constant over the last years (Slemr et al., 2011). Those and similar results have been obtained both from the evaluation of continuous measurements conducted at monitoring sites (e.g. Mace Head and Cape Point) 
as well as from ship cruises (e.g. Slemr et al., 1985; Temme et al., 2003).

In order to understand the global cycling of mercury in the atmosphere several long term measurement sites have been established. Most of them are located in the latitude band between $40^{\circ} \mathrm{N}$ and $60^{\circ} \mathrm{N}$ (Slemr et al., 2011). In the SH the only continuous measurements are at Cape Point, South Africa (e.g. Slemr et al., 2008; Brunke et al., 2010) and Antarctica (Pfaffhuber et al., 2011). The most severe lack of measurement sites exists in the tropics, a region where several potentially important exchange processes are taking place. For example, Ebinghaus et al. (2007) suggested that biomass burning, mainly occurring in the tropics, represents a large source of atmospheric mercury for the SH during the burning season in August-October. In South America gold mining is known to contribute significantly to the mercury burden (Sprovieri et al., 2010), and especially in the tropics, wetlands are thought to be an important source, too. Until recently mercury data for the tropics were only available from short term measurement campaigns. The first long-term measurement site in the tropics was installed in Nieuw Nickerie (Suriname, South America) in 2007 (Wip et al., 2012). Due to a lack of funding the measurements had to be discontinued, but operation has been resumed in 2011 within the GMOS project. In this work data from the first year of operation is presented. The focus will be the investigation of the influence of the intertropical convergence zone (ITCZ) movement over the site.

\section{Methods}

\subsection{Site description and experimental setup}

The data were obtained at Nieuw Nickerie $\left(5^{\circ} 56^{\prime} \mathrm{N}\right.$, $56^{\circ} 59^{\prime} \mathrm{W}$ ), Suriname, a tropical site on the northeastern coast of the South American continent. Nieuw Nickerie is a coastal city of about 13000 residents and lies on the Nickerie River in the west of Suriname. Surrounding land is used primarily for agriculture such as rice cultivation. Although mining, including industrial and artisanal gold mining, is a major industry and emitter of mercury in Suriname, major mine sites are located further away towards the southeast in the interior of the country.

The measurement site is of special interest for several reasons. First, it provides the first continuous mercury measurements in the tropics and thereby closes a gap in the global atmospheric mercury monitoring network. It is therefore very meaningful for the investigation of the latitudinal gradient in mercury concentrations. Secondly, the ITCZ migrates over the site, which makes it possible to study $\mathrm{NH}$ as well as $\mathrm{SH}$ air at this site during different times of the year. During the long dry season (July-November) the ITCZ is located north of the Surinamese coastal plain and south of it during the short dry season (February-April). Two short rainy seasons occur each year when the ITCZ passes overhead. The trade winds carry air from the $\mathrm{NH}$ in the first half of the year and from the SH in the second half. Prevailing winds and backward trajectories suggest that the air arriving at Nieuw Nickerie is mainly clean marine air from the Atlantic; hence the station can be taken as representative for the tropical Atlantic.

Mercury concentrations have been measured with a Tekran 2537A Mercury Vapour Analyzer. This instrument preconcentrates ambient mercury vapour on two gold cartridges, which are then alternately degassed and quantified by Cold Vapour Atomic Fluorescence Spectrometry. The instrument was calibrated every $13 \mathrm{~h}$ with an internal permeation source. Afterwards the data quality can be tested by comparing the results from the two cartridges.

It has recently been discussed whether the Tekran instrument measures total gaseous mercury $(\mathrm{TGM}=\mathrm{GEM}+$ RGM) or GEM only (Slemr et al., 2011). Models (see below) suggest that RGM is $<2 \%$ at our site in Suriname. We consider the Tekran data to represent TGM in line with previous studies (e.g. Kock et al., 2005; Slemr et al., 2008).

\subsection{Data processing}

Concentrations above $3 \mathrm{ng} \mathrm{m}^{-3}$, very likely representing local pollution events, were excluded from investigation. There are gaps in the measurement record because of cleaning of the cartridges, pump replacement and other technical reasons. Therefore the measurements in 2007 are only available for the months March to October. Comparing the results from the two cartridges revealed a failure of cartridge B in 2007, possibly due to passivation of the gold trap or an intermittent failure of the heating coil. Therefore only data from cartridge A were used in this time span.

\subsection{Back trajectories}

For this investigation 10-day back trajectories were calculated from the Hybrid Single-Particle Lagrangian Integrated Trajectory (HYSPLIT-4) model (Draxler and Hess, 1997, 1998; Draxler, 1999). The NCEP reanalysis data set was used as meteorological input. The trajectories were initialized every $12 \mathrm{~h}$ at starting heights $100 \mathrm{~m}, 500 \mathrm{~m}, 1000 \mathrm{~m}$ and $1500 \mathrm{~m}$ above Nieuw Nickerie, and trajectory histories were output hourly.

\subsection{Reference sites}

In the following, the Nieuw Nickerie data will also be set in relation to data from Mace Head $\left(53^{\circ} 20^{\prime} \mathrm{N}, 9^{\circ} 54^{\prime} \mathrm{W}\right)$, Ireland (Kock et al., 2005; Ebinghaus et al., 2002, 2011), and Cape Point $\left(34^{\circ} 21^{\prime} \mathrm{S}, 18^{\circ} 29^{\prime} \mathrm{E}\right)$, South Africa (Slemr et al., 2008, 2011; Brunke et al., 2010). These sites provide a reference point in each hemisphere for TGM concentrations over the Atlantic Ocean. At all sites, mercury has been measured with the Tekran instrument and can thus be directly intercompared. Mace Head data cover the whole year 2007 while 


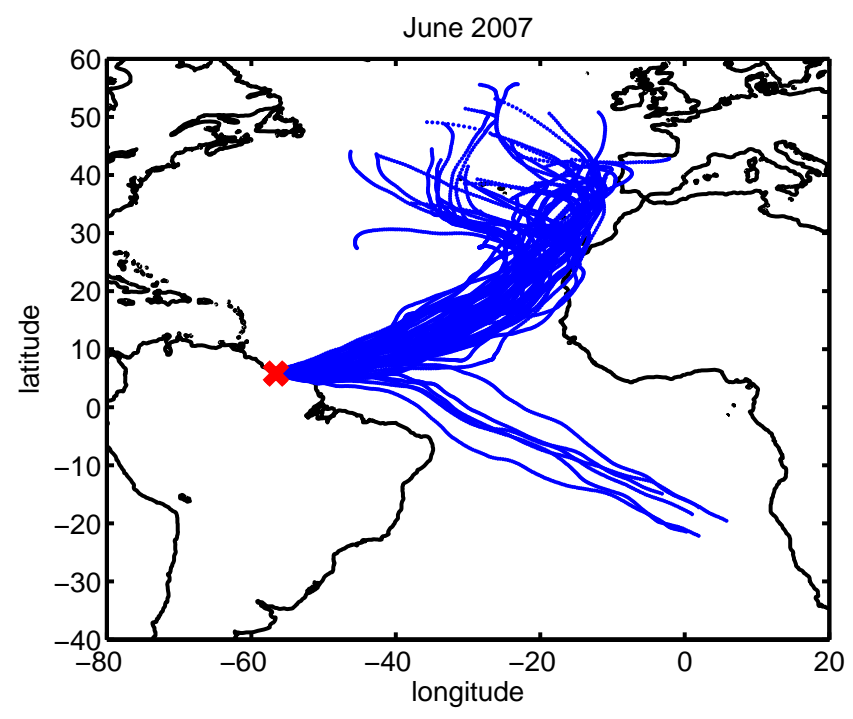

Fig. 1. A batch of 10 days backward trajectories from HYSPLIT4 in June 2007 (blue) indicating that the air comes from the open ocean most of the time. The red cross marks the measurement location.

Cape Point data were only available from March to December 2007.

\subsection{Model data}

In the course of this study the Nieuw Nickerie data were compared to two 3-D chemistry and transport model simulations. One is obtained from a recent version of Environment Canada's Global/Regional Atmospheric Heavy Metals Model (GRAHM), described in detail by Durnford et al. (2012). Meteorological and mercury processes are fully integrated in the GRAHM online meteorological-chemical predictive model. In this work, the latest version of the model with a $2^{\circ} \times 2^{\circ}$ horizontal resolution was used. The model was sampled in a grid cell centered at $5^{\circ} \mathrm{N}, 57^{\circ} \mathrm{W}$, which includes Nieuw Nickerie.

The other model used in this study is the most recent version of the GEOS-Chem mercury model, described in detail by Holmes et al. (2010), with a coupled ocean model described by Soerensen et al. (2010). The model horizontal resolution is $4^{\circ} \times 5^{\circ}$. The model was sampled in the grid cell containing the site and centered at $6^{\circ} \mathrm{N}, 55^{\circ} \mathrm{W}$. The GEOSChem mercury model is available in two chemistry versions, one including oxidation of $\mathrm{Hg}$ by bromine, the other one including oxidation by $\mathrm{O}_{3}$ and $\mathrm{OH}$ (Holmes et al., 2006, 2010). At Nieuw Nickerie the two chemistry versions produce similar results, so only the $\mathrm{Hg}+\mathrm{Br}$-version is shown in the comparison below.

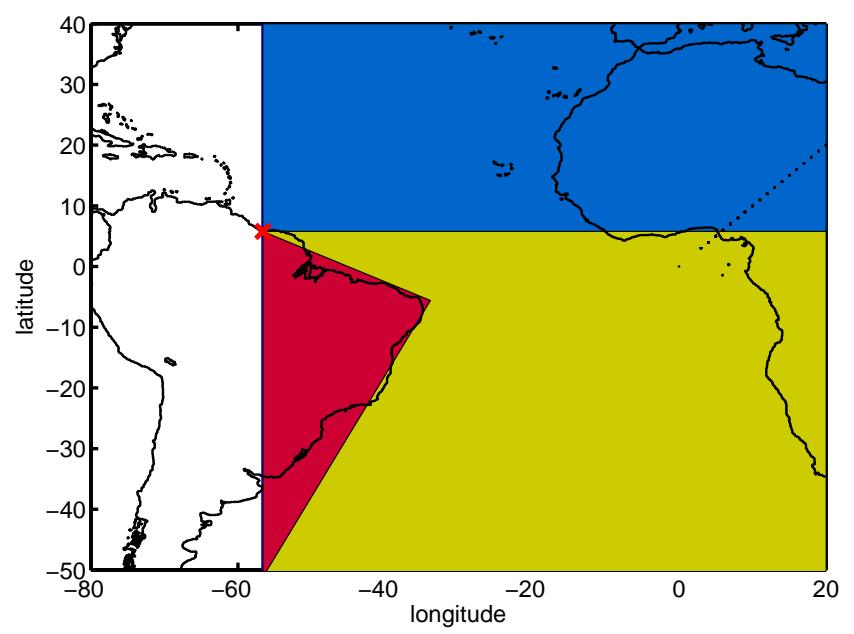

Fig. 2. Zones referred to as NH marine air ("NH", blue), SH marine air ("SH", yellow) and SH continental air ("Land", red). No trajectories passed through the white section in the 10 days before reaching Nieuw Nickerie. The red cross marks the measurement location.

\section{Results}

The backward trajectories indicate that the air arriving at Nieuw Nickerie comes from the open ocean most of the time (see Fig. 1). However, sometimes the air masses also pass over the South American continental land mass. To separate clean marine air in the following analysis, backward trajectories were used to figure out the times when marine or continental air reached the measurement location. The condition for defining an air parcel as marine air was that it had not remained over land for more than $3 \mathrm{~h}$. This criterion was chosen in order to eliminate air masses impacted by land sources, but still include air masses from the marine sector that passed briefly over land en route to the measurement site. Figure 2 shows the 3 different trajectory categories: NH marine air, $\mathrm{SH}$ marine air and $\mathrm{SH}$ continental air, hereafter referred to as "NH", "SH", and "Land". Trajectory starting heights of 100 or $500 \mathrm{~m}$ provide similar air classifications, but higher starting altitudes produce different results, likely because of a trade wind inversion that can form above $1000 \mathrm{~m}$ so these would not be representative of surface air. The following analysis uses $500 \mathrm{~m}$ starting heights.

\subsection{NH/SH/Land difference}

With the help of the above mentioned condition, the data were assigned to one of the three zones, and mercury distribution characteristics were calculated for all of them. They are shown in Table 1 and Fig. 3. Two things can be stated: First, the $\mathrm{Hg}$ concentrations in the $\mathrm{NH}$ air are about $0.13 \mathrm{ng} \mathrm{m}^{-3}$ higher than in the $\mathrm{SH}$ air. Second, the concentrations in the continental $\mathrm{SH}$ air are about $0.10 \mathrm{ng} \mathrm{m}^{-3}$ higher than in the marine $\mathrm{SH}$ air. The $\mathrm{NH} / \mathrm{SH}$ concentration 
Table 1. Characteristics of the data assigned to one of the zones "NH", "SH", or "Land". $\bar{x}_{\text {arith }}$ : mean, $\bar{x}_{\text {med }}$ : median, $\sigma_{\mathrm{m}}$ : standard deviation of the mean, $\sigma$ : standard deviation.

\begin{tabular}{lcccc}
\hline & $\begin{array}{c}\bar{x}_{\text {arith }} \\
\left(\mathrm{ng} \mathrm{m}^{-3}\right)\end{array}$ & $\begin{array}{c}\bar{x}_{\text {med }} \\
\left(\mathrm{ng} \mathrm{m}^{-3}\right)\end{array}$ & $\begin{array}{c}\sigma_{\mathrm{m}} \\
\left(\mathrm{ng} \mathrm{m}^{-3}\right)\end{array}$ & $\begin{array}{c}\sigma \\
\left(\mathrm{ng} \mathrm{m}^{-3}\right)\end{array}$ \\
\hline NH & 1.450 & 1.439 & 0.004 & 0.268 \\
SH & 1.324 & 1.309 & 0.004 & 0.225 \\
Land & 1.428 & 1.407 & 0.009 & 0.252 \\
\hline
\end{tabular}

ratio is 1.10 , both for the means and for the medians. For the histogram plot (Fig. 3), a bin size of $0.10 \mathrm{ng} \mathrm{m}^{-3}$ was chosen, for each bin the relative frequency was calculated. Figure 3 suggests that the concentrations are normally distributed around the mean (skewness near zero) and that systematic influences, e.g. meteorology and seasonality, can be regarded as second order effects. A Gaussian curve was fitted to each dataset $(\mathrm{NH} / \mathrm{SH})$, indicating the normal distribution.

\subsection{Continental mercury sources}

The fact that SH continental air Hg concentrations are higher than $\mathrm{SH}$ marine air $\mathrm{Hg}$ concentrations indicates that in the tropics the continents appear to have larger sources than the ocean. This applies here particularly for the months August and September, which are the months with the most air masses going over land (on 10 days in August, 4 days in September). A continental source that has a significant impact during those months is biomass burning. Figure 4 shows emission maps obtained from the Global Fire Emission Database (GFED3) inventory (van der Werf et al., 2010), assuming a $\mathrm{Hg} / \mathrm{CO}$ emission ratio of $100 \mathrm{nmol} \mathrm{mol}^{-1}$ (Holmes et al., 2010). It can be seen that in August and September emissions from biomass burning are high in the Brazilian Amazon. During this period, biomass burning emissions of mercury exceed anthropogenic emissions (Ebinghaus et al., 2007) and also exceed total terrestrial and anthropogenic emissions from South America calculated within the GEOSChem model.

\subsection{Comparison to reference sites}

Figure 5 shows how the tropical site at Nieuw Nickerie fits into the North-South-gradient over the Atlantic from Mace Head in the North to Cape Point in the South. The means are calculated from the availabe data in 2007, that is, for Mace Head, January to December, and for Cape Point, it is March to December. The Nieuw Nickerie means are the same as in Table 1 . On the one hand, the decrease of mercury concentrations from North to South seems to be rather continuous, as formerly indicated by data obtained during ship cruises (Temme et al., 2003). On the other hand, Slemr et al. (1985) hypothesized that TGM is rather uniformly distributed over the SH. If this was true, the difference between Nieuw Nick-

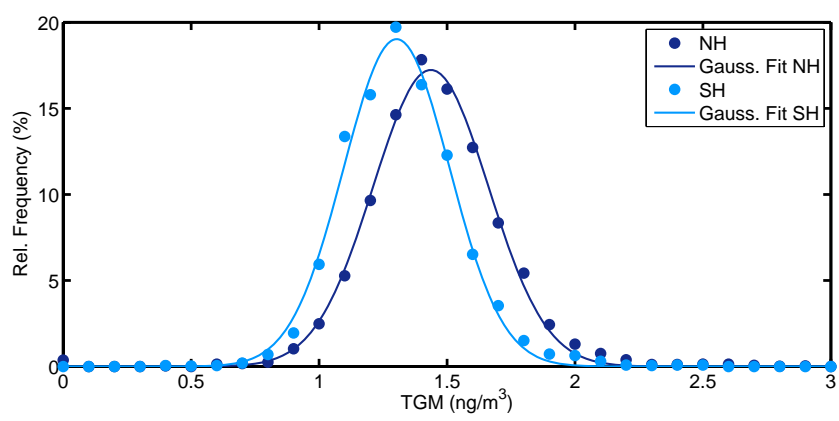

Fig. 3. Histogram showing the distribution of mercury concentrations measured during $\mathrm{NH}$ influence (dark blue) and $\mathrm{SH}$ influence (light blue). The dots represent the relative frequency for the particular bin, the lines represent Gaussian curves fitted to the data, indicating that the data are normally distributed.

erie (SH) and Cape Point mercury concentrations could indicate the existence of important mercury sources in the tropics.

\subsection{Model comparison}

Eventually, the seasonal variation of mercury concentrations in Nieuw Nickerie, which is of course also related to the ITCZ movement, was compared to simulations obtained from GRAHM and GEOS-Chem, respectively. Monthly means were calculated. The result is shown in Fig. 6. It can be seen that both models overestimate the magnitude of the mercury concentrations. In addition, a greater seasonal amplitude is predicted by both GRAHM and GEOS-Chem. In GEOS-Chem, the transition from higher to lower $\mathrm{Hg}$ values starts earlier than in GRAHM: Hg concentrations start decreasing in April, whereas in GRAHM, the transition begins in June in agreement with the observations. Nevertheless, a lack of agreement can be observed in March and April. The reason for this remains speculative. Since there is a lot of uncertainty about natural emissions of mercury (Mason et al., 2009), this appears to be a potential reason. It should be noted here that the models are using anthropogenic mercury emissions at 2005 level since more recent emission inventory is currently unavailable. Inaccurate anthropogenic emissions could have significant impact on predicted NH background concentrations.

Both models exhibit an overall high bias relative to the observations. For the months with observations (March-October), GEOS-Chem averages $1.55 \mathrm{ng} \mathrm{m}^{-3}$ while GRAHM averages $1.56 \mathrm{ng} \mathrm{m}^{-3}$, compared to the observed mean of $1.40 \mathrm{ng} \mathrm{m}^{-3}$. The mean of both models is much closer to the observations during July-October, when Nieuw Nickerie samples mainly SH air. As discussed above, the GEOS-Chem model has variants with different atmospheric oxidants for elemental mercury. Figure 5 uses the model variant with bromine oxidant, but the overall bias and excessively large seasonal cycle at Nieuw Nickerie are very similar 
Jan 2007
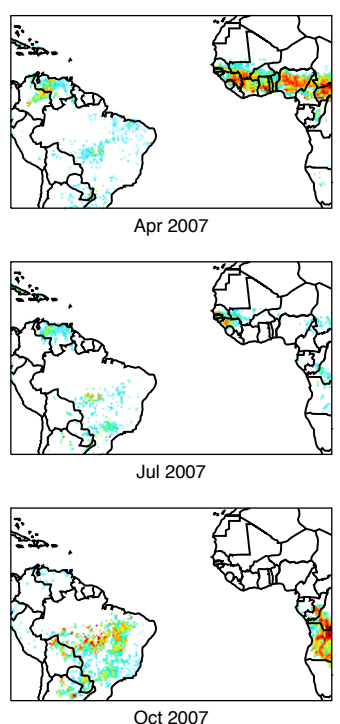

Oct 2007

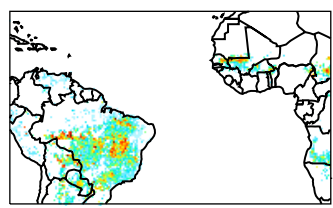

Feb 2007
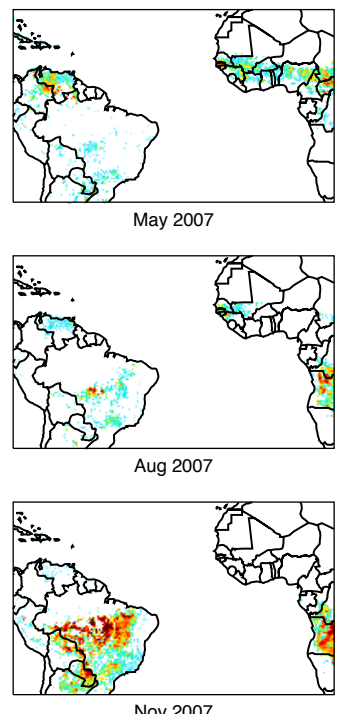

Nov 2007

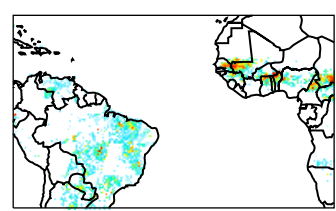

Mar 2007

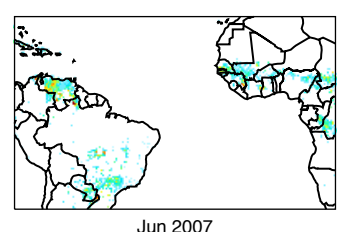

ug $\mathrm{m}^{-2} \mathrm{a}^{-}$

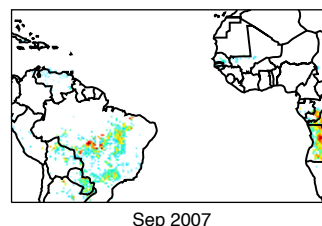

500

200

100

50

20

10

5

2

0.0

Fig. 4. Maps showing the mercury emissions from fire on the South American and African continent obtained from the GFED3 inventory for each month in 2007. It can clearly be seen that especially in August and September fire emissions are high on the South American continent.

with $\mathrm{OH}$ and $\mathrm{O}_{3}$ as oxidants. Initial simulations for this work used an earlier version of the surface ocean component of the GEOS-Chem model (Strode et al., 2007). This earlier version contains a less mechanistic representation of marine chemistry controlling mercury emissions, but nevertheless produced a smaller amplitude seasonal cycle at Nieuw Nickerie and smaller bias relative to the observations. This suggests that ocean emissions, rather than mercury sinks, can account for the model deficiencies. Since ocean mercury modelling to date has been constrained mainly by observations and process studies in mid latitudes (Soerensen et al., 2010), there are large uncertainties in the tropical marine fluxes, as well as globally (Qureshi et al., 2011).

\section{Summary and conclusion}

In this study a dataset of atmospheric mercury concentrations obtained at a tropical site in Nieuw Nickerie, Suriname, has been evaluated for the year 2007. Due to the ITCZ movement in this region the concentrations are influenced by both the $\mathrm{NH}$ and the SH. Using HYSPLIT-4 backward trajectories, the data were assorted into continental, $\mathrm{NH}$ marine and $\mathrm{SH}$ marine air data. It was shown that the $\mathrm{NH}$ concentrations are higher than the SH concentrations, and so are the continental ones.

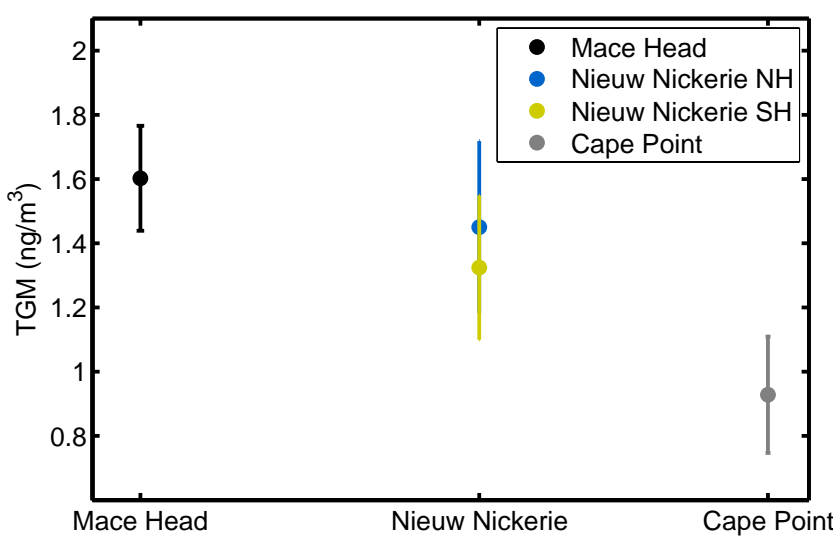

Fig. 5. Annual mean concentrations of total gaseous mercury in 2007 and their latitudinal dependence. The mean for Mace Head was calculated from January-December, the means for Nieuw Nickerie are the same as in Table 1 and hence derived as described in the text. The Cape Point mean was calculated from MarchDecember. The distance between the sites on the horizontal axis corresponds to their distance in latitudes. Error bars represent one standard deviation.

Consequently, there is a North-South-gradient, which is true both for this single site, but also if the Nieuw Nickerie SH data are compared to Cape Point as a reference site. 


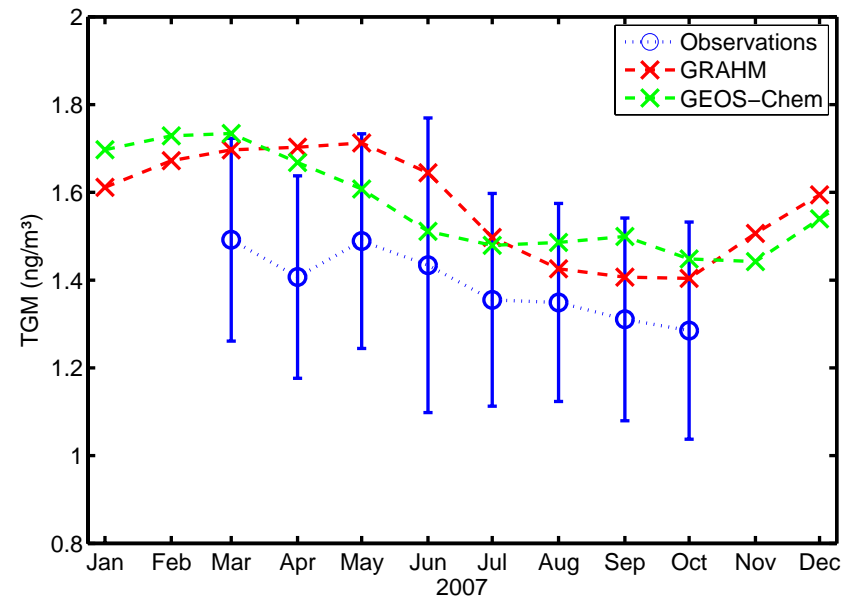

Fig. 6. Monthly means of mercury concentrations measured in Nieuw Nickerie (blue) and simulated by GRAHM (red) and GEOSChem (green). Error bars of the observational data represent one standard deviation. The model data are plotted without error bars. Dashed lines are for orientation.

If the mercury concentrations in the $\mathrm{SH}$, as represented by Cape Point, are rather uniformly distributed over the hemisphere (as hypothesized by Slemr et al., 1985), but still higher in the tropics, local sources must be expected in the latter. Regarding the fire emission maps obtained from GFED3 it was hypothesized that mercury emissions from biomass burning might contribute to the higher concentrations in the SH continental air. However this does not mean that other sources, like, e.g. wetlands, do not contribute at a similar magnitude. This still has to be investigated.

Comparing the model simulations from GRAHM and GEOS-Chem to the observed mercury concentrations, it could be stated that the transport seems reasonably well implemented in the models. However, the different absolute values suggest that the uncertainty of, e.g. natural emissions and among them probably ocean emissions still restricts the ability of models to adequately simulate atmospheric mercury concentrations. Conclusively, identifying and quantifying natural and other sources of mercury emissions in the tropics is an important task for future research.

Acknowledgements. The measurements in Nieuw Nickerie were started as part of the UNEP-project "Strengthening Surinamese involvement in activities related to mercury pollution in Suriname" (SURIMERC). In addition we would like to acknowledge funding by the 7th framework project of the EC "GMOS". We are grateful to Cor Becker and his team of the Meteorological Service of Suriname providing the infrastructure for the measurements. The Tekran mercury analyzer in Nieuw Nickerie was provided by H. E. Scheel (Forschungszentrum Karlsruhe, IMK-IFU, Germany). Furthermore, we thank Ernst-Günther Brunke from the South African Weather Service for making mercury data available collected at the Cape Point Global Atmosphere Watch (GAW) station. We also thank Ralf Ebinghaus from the Institute of Coastal Research, Helmholtz-Zentrum Geesthacht, for his continuous support during this work.

Edited by: R. Ebinghaus

\section{References}

Brunke, E.-G., Labuschagne, C., Ebinghaus, R., Kock, H. H., and Slemr, F.: Gaseous elemental mercury depletion events observed at Cape Point during 2007-2008, Atmos. Chem. Phys., 10, 11211131, doi:10.5194/acp-10-1121-2010, 2010.

Durnford, D., Dastoor, A., Ryzhkov, A., Poissant, L., Pilote, M., and Figueras-Nieto, D.: How relevant is the deposition of mercury onto snowpacks? - Part 2: A modeling study, Atmos. Chem. Phys. Discuss., 12, 2647-2706, doi:10.5194/acpd-122647-2012, 2012.

Draxler, R. R. and Hess, G. D.: Description of the HYSPLIT_4 modeling system. NOAA Tech. Memo. ERL ARL-224, NOAA Air Resources Laboratory, Silver Spring, MD, 24 pp., 1997.

Draxler, R. R. and Hess, G. D.: An overview of the HYSPLIT_4 modeling system of trajectories, dispersion, and deposition, Aust. Meteor. Mag., 47, 295-308, 1998.

Draxler, R. R.: HYSPLIT4 user's guide, NOAA Tech. Memo. ERL ARL-230, NOAA Air Resources Laboratory, Silver Spring, MD, 1999.

Ebinghaus, R., Tripathi, R. M., Wallschläger, D., and Lindberg, S. E.: Natural and Anthropogenic Mercury Sources and Their Impact on the Air-Surface Exchange of Mercury on Regional and Global Scales, in: Mercury Contaminated Sites - Characterization, Risk Assessment and Remediation, edited by: Ebinghaus, R., Turner, R. R., de Lacerda, L. D., Vasiliev, O., and Salomons, W., Springer, Berlin/Heidelberg, 1999.

Ebinghaus, R., Kock, H. H., Coggins, A. M., Spain, T. G., Jennings, S. G., and Temme, C.: Long-term measurements of atmospheric mercury at Mace Head, Irish west coast, between 1995 and 2001, Atmos. Environ., 36, 5267-5276, 2002.

Ebinghaus, R., Slemr, F., Benninkmeijer, C. A. M., van Velthoven, P., Zahn, A., Hermann, M., O'Sullivan, D. A., and Oram, D. E.: Emissions of gaseous mercury from biomass burning in South America in 2005 observed during CARIBIC flights, Geophys. Res. Lett., 34, L08813, doi:10.1029/2006GL028866, 2007.

Holmes, C. D., Jacob, D. J., and Yang, X.: Global lifetime of elemental mercury against oxidation by atomic bromine in the free troposphere, Geophys. Res. Lett., 33, L20808, doi:10.1029/2006GL027176, 2006.

Holmes, C. D., Jacob, D. J., Corbitt, E. S., Mao, J., Yang, X., Talbot, R., and Slemr, F.: Global atmospheric model for mercury including oxidation by bromine atoms, Atmos. Chem. Phys., 10, 12037-12057, doi:10.5194/acp-10-12037-2010, 2010.

Kock, H. H., Bieber, E., Ebinghaus, R., Spain, T. G., and Thees, B.: Comparison of long-term trends and seasonal variations of atmospheric mercury concentrations at the two European coastal monitoring stations Mace Head, Ireland, and Zingst, Germany, Atmos. Environ., 39, 7549-7556, doi:10.1016/j.atmosenv.2005.02.059, 2005.

Lindberg, S., Bullock, R., Ebinghaus, R., Engstrom, D., Feng, X., Fitzgerald, W., Pirrone, N., Prestbo, E., and Seigneur, C.: A Syn- 
thesis of Progress and Uncertainties in Attributing the Sources of Mercury in Deposition, Ambio, 36, 19-33, 2007.

Mason, R. P.: Mercury emissions from natural processes and their importance in the global mercury cycle, in: Mercury Fate and Transport in the Global Atmosphere: Emissions, Measurements and Models, edited by: Pirrone, N. and Mason, R. P., Chapter 7, Springer, 173-191, 2009.

Pfaffhuber, K. A., Berg, T., Hirdman, D., and Stohl, A.: Atmospheric mercury observations from Antarctica: seasonal variation and source and sink region calculations, Atmos. Chem. Phys., 12, 3241-3251, doi:10.5194/acp-12-3241-2012, 2012.

Pirrone, N., Cinnirella, S., Feng, X., Finkelman, R. B., Friedli, H. R., Leaner, J., Mason, R., Mukherjee, A. B., Stracher, G. B., Streets, D. G., and Telmer, K.: Global mercury emissions to the atmosphere from anthropogenic and natural sources, Atmos. Chem. Phys., 10, 5951-5964, doi:10.5194/acp-10-59512010, 2010.

Qureshi, A., MacLeod, M., and Hungerbühler, K.: Quantifying uncertainties in the global mass balance of mercury, Global Biogeochem. Cy., 25, GB4012, doi:10.1029/2011GB004068, 2011.

Slemr, F., Schuster, G., and Seiler, W.: Distribution, Speciation, and Budget of Atmospheric Mercury, J. Atmos. Chem., 3, 407-434, 1985.

Slemr, F., Brunke, E.-G., Labuschagne, C., and Ebinghaus, R.: Total gaseous mercury concentrations at the Cape Point GAW station and their seasonality, Geophys. Res. Lett., 35, L11807, doi:10.1029/2008GL033741, 2008.

Slemr, F., Brunke, E.-G., Ebinghaus, R., and Kuss, J.: Worldwide trend of atmospheric mercury since 1995, Atmos. Chem. Phys., 11, 4779-4787, doi:10.5194/acp-11-4779-2011, 2011.
Soerensen, A. L., Sunderland, E. M., Holmes, C. D., Jacob, D. J., Yantosca, R. M., Skov, H., Christensen, J. H., Strode, S. A., and Mason, R. P.: An Improved Global Model for Air-Sea Exchange of Mercury: High Concentrations over the North Atlantic, Environ. Sci. Technol., 44, 8574-8580, 2010.

Sprovieri, F., Pirrone, N., Ebinghaus, R., Kock, H., and Dommergue, A.: A review of worldwide atmospheric mercury measurements, Atmos. Chem. Phys., 10, 8245-8265, doi:10.5194/acp10-8245-2010, 2010.

Strode, S. A., Jaeglé, L., Selin, N. E., Jacob, D. J., Park, R. J., Yantosca, R. M., Mason, R. P., and Slemr, F.: Air-sea exchange in the global mercury cycle, Global Biogeochem. Cy., 21, GB1017, doi:10.1029/2006GB002766, 2007.

Temme, C., Einax, J. W., Ebinghaus, R., and Schroeder, W. H.: Measurements of Atmospheric Mercury Species at a Coastal Site in the Antarctic and over the South Atlantic Ocean during Polar Summer, Environ. Sci. Technol., 37, 22-31, 2003.

van der Werf, G. R., Randerson, J. T., Giglio, L., Collatz, G. J., Mu, M., Kasibhatla, P. S., Morton, D. C., DeFries, R. S., Jin, Y., and van Leeuwen, T. T.: Global fire emissions and the contribution of deforestation, savanna, forest, agricultural, and peat fires (19972009), Atmos. Chem. Phys., 10, 11707-11735, doi:10.5194/acp10-11707-2010, 2010.

Wip, D., Warneke, T., Notholt, J., and Müller, D.: Variations of mercury concentrations in tropical Atlantic air, in preparation, 2012. 